\title{
Health Risk Behaviors among Port Said University Students
}

\author{
Asmaa Gomaa Salem ${ }^{1}$, Gehad Mohamed Abo-Elmatty², Reda Ibrahim El-Mowafy ${ }^{3}$ \\ Hannan Hassan El-Ezaby ${ }^{4}$
}

B.Sc. Nursing, Faculty of Nursing, Suez Canal University. Professor of Family and Community Health Nursing, Faculty of Nursing, Port Said University, Assistant professor of Family and Community Health Nursing, Faculty of Nursing, Port Said University, assistant professor of Family and Community Health Nursing, Faculty of Nursing, Port Said University.

\begin{abstract}
Background: Health risk behaviors are one of the most important aspects of human health. The aim of this study was to determine the health risk behaviors among Port Said University students and identify factors related to it. Setting: the study was carried out at all faculties of Port Said University. Sample: the sample size was 700 students stratified randomly selected. Research design: a cross sectional descriptive design was used. Data collection tools: Self administered a standardized questionnaire was used to collect data, it includes two parts part one includes socio demographic data, the second part includes: modified and tested version of National College Health Risk Behavior Surveillance System Questionnaire (NCHRBSS).Results: The results indicated that the majority of the studied students, $79.5 \%$ never or rarely wore a seat belt while driving, $6.3 \%$ of students had participated in physical fights, $\mathbf{1 0 . 9} \%$ of the students were planning suicide attempts, $\mathbf{3 . 0} \%$ were drug users, $\mathbf{2 . 9} \%$ were alcohol consumers, $\mathbf{1 1 . 0} \%$ were smoked, and $\mathbf{6 . 3} \%$ of the student were sexually active. In addition, $45.5 \%$ of the students had unhealthy dietary habits, where $69.0 \%$ of them did not practice physical activities regularly. Conclusion: physical inactivity had been the most prevalent health risk behavior followed by, unhealthy dietary habits, then unintentional injuries. Recommendations: physical activity and nutritional programs should be carried to university student's healthy lifestyle behaviors.
\end{abstract}

Key words: health risk behaviors, university students. 


\section{INTRODUCTION}

Health risk behaviors are defined as engaging in any activity with a frequency or intensity that increases risk of disease or injury. They are considered the most serious threat to health and well-being. Everyone may engage in more than one risk behavior at the same time, thus these risk behaviors are interrelated and might cluster together into a risky lifestyle. Health risk behaviors can lead to negative health outcomes as unwanted pregnancy, sexually transmitted diseases, severe disability and death (McDermott, 2012).

Health risk behaviors are prevalent during all stages of development, but they are especially noticed during adolescence and young adulthood. Adolescence and young adulthood periods are one of the most important periods of human development due to physical, psychological and sexual changes occurring during these periods. World Health Organization (WHO) is defined young adults as people aged 18-24 years. University students are in this category, they comprise a quarter of the world's population, and nearly 90\% of them live in low-income and middle-income countries (United Nations Program on HIV/AIDS, Program Coordinating Board (UNAIDS/PCB) and WHO, 2013).

The National College Health Risk Behavior Survey (NCHRBS) and Youth Risk Behavior Surveillance System (YRBSS) have developed by CDC since 1999 to monitor six categories of risk behaviors. These behaviors are: 1) Behaviors that contribute to unintentional injuries and violence; 2) Tobacco use; 3) Alcohol and drug use; 4) Sexual behaviors that contribute to unintended pregnancy and sexual transmitted disease, including human immunodefiency virus infection; 5) Unhealthy dietary behaviors and 6) Physical inactivity( CDC, 2016).

Approximately two-thirds of premature deaths among adults are associated with behaviors that were initiated during adolescence. Furthermore, one-third of the disease morbidity in adults is associated with behaviors that started before adulthood, including tobacco use, risky sexual behaviors, inadequate physical activity, and violence (WHO, 2011). 
University students engage in health risk behaviors more than any other population for several factors as being not fully capable of understanding complex concepts as the relationship between behavior and consequences, separation from their families, facing peer pressures and exposure to new experiences. Also, the university is the time for identity development. Moreover, age, socioeconomic level, gender, parents' level of education, family monthly income and environmental factors such as family, school, and community characteristics are significant contributors to unhealthy lifestyles (Bhubaneswar, 2014).

Egypt, like many Middle Eastern countries, is experiencing a "youth bulges." youth aged 15-24 years constituted over 30\% of Egypt's population or about 22 millions. The behaviors they establish now will affect Egypt's health and development indicators, and health care spending for many years. Education is an essential part of many young people's lives and school is a place to interact with peers and people outside of one's family (Harbour, 2010). The current situation in Egypt demonstrates that, although adolescents have historically been neglected as an age group requiring particular attention, interest in the rights and needs of adolescents has grown since the 25th of January revolution, which dramatically demonstrated the important role young people play as catalysts for change (Ansari et al, 2016).

The role of the community health nurse in serving as a team member in providing preventive services, early identification of health risk behaviors, interventions, and referrals is important to foster health and educational success. Controlling these risky behaviors early in life may help decrease the burden of non-communicable diseases in adult life, and thus decrease the pressure on society and the health care system (Lundy and Janes, 2016).

\section{Significance of the Study:-}

Data on health risk behaviors among university students in Port Said are lacking.It is necessary to collect baseline information about the magnitude of the problem, risk factors, and consequences of these health risk behaviors among those students and accordingly, more detailed information about them and their health risk behaviors will be available to universities that may help the decision makers for the development of future prevention and intervention programs for this particularly at risk college students. So this 
study carried out to determine the concurrent health risk behaviors among university students in Port Said University.

\section{AIM OF THE STUDY}

This study aimed to determine the health risk behaviors among Port Said University students.

\section{Research Objectives}

1-To assess the health risk behaviors among university students.

2-To identify the factors related to health risk behaviors among university students.

\section{SUBJECTS AND METHOD}

\section{Study Design \& Setting}

A descriptive cross-sectional research design was used, carried out at all faculties ( twelve) that affiliated with Port Said University, namely (Faculty of Commerce, Faculty of Engineering, Faculty of Physical education, Faculty of Kinder garden, Faculty of Computer Science, Faculty of Medicine, Faculty of pharmacy, Faculty of Nursing, Faculty of Science, Faculty of Arts, Faculty of education, and Faculty of education).

\section{Study Sample}

The subjects of the study compromised of 700 students from the mentioned twelve faculties. (3.6\%) from each faculty. The total students in the above faculties were (19254) student, they were distributed at the following.

\begin{tabular}{|l|c|c|}
\hline \multicolumn{1}{|c|}{ Faculty } & Total Number of Students & Sample Number \\
\hline Faculty of Commerce & 6473 & 235 \\
\hline Faculty of Engineering & 2251 & 82 \\
\hline Faculty of Physical education & 978 & 36 \\
\hline Faculty of Kinder garden & 236 & 9 \\
\hline Faculty of Computer Science & 1904 & 69 \\
\hline Faculty of Medicine & 302 & 11 \\
\hline Faculty of pharmacy & 416 & 15 \\
\hline Faculty of Nursing & 427 & 16 \\
\hline Faculty of Science & 791 & 29 \\
\hline Faculty of Arts & 2573 & 93 \\
\hline Faculty of Education & 1477 & 53 \\
\hline Faculty of Specific education & 1428 & 52 \\
\hline Total & 19254 & 700 \\
\hline
\end{tabular}




\section{Sampling technique}

Stratified random Sampling was used in this study. All students in the above mentioned faculties in Port Said University were randomly selected according to the following criteria:

\section{Inclusion Criteria:}

1. Students aged from $18-24$ years,

2. Both sexes,

3. Single students.

Sample size from each faculty was estimated by using the following equation ( $\mathrm{p}=\mathrm{n} 1 / \mathrm{Nxn})$ where $\mathrm{p}=$ proportional sample, $\mathrm{n} 1=$ total population for the faculty, $\mathrm{N}=$ total number of all sampled faculties, $\mathrm{n}=$ estimated sample, Based on this equation, sample size for each faculty was determined.

\section{Sample size calculations:}

The sample size was determined by using the following equation

$$
\text { Sample size }(\mathrm{n})=(\mathrm{z} / \Delta)^{2} \mathrm{p} \quad(100-\mathrm{p}) \text {. (Dobson, A. J., 2002): }
$$

\section{Where:}

P: The prevalence of unhealthy sexual behavior $=48 \%$.

$\mathbf{Z \alpha} / \mathbf{2}$ : a percentile of standard normal distribution determined by confidence level $=1.96$

$\Delta:$ The width of confidence interval $=5 \%$

\section{Sample Size $(n)=689.58$}

The calculated Sample size is, Due to the expected non-participating rate (5\%); the final sample size $=\mathbf{7 0 0}$ 
Tools of data collection: Data were collected using the following two tools

A self-administered questionnaire was included version of the National College Health Risk Behavior Surveillance system (NCHRBSS) Questionnaire developed by the Centers for Disease Control and Prentveion (CDC), it was modified and translated by (Hassan, 2013), and remodified by the researcher. It's divided into two parts:

\section{First part:}

Consists of two items which are; First: Socio demographic characteristics which include gender, age, religion, weight, length, current residence, current living place, history of a chronic disease. Second: Family characteristics which include family Members, the number of house room, educational level of the father, educational level of the mother, monthly family income and a family history of health risk behaviors.

\section{Second part:}

It consists of 6 items with (42) a subscale each of these items the answer (yes) rated by 1 and the answer (no) rated by 2, this part examine six health risk behaviors:1- Behaviors leading to unintentional injuries which include physical fights, wearing seat belts, carrying weapons, physical fights, and the suicidal attempts with (6) subscales.2- Smoking behaviors, the types of smoking, the first time of smoking, the pattern of smoking, and quantity of smoking with (6) subscales.3- Alcohol and substance abuse behaviors which include, the current drinking, the first time, the quantity of drinking, and the substance abuse which includes, the substance type, the first time, and the quantity, the taking narcotic drugs or sedatives without a prescription with (9) subscales.4- Sexual behaviors, the first time of practicing sex, the partners, sexual harassment, HIV testing with (7) subscales.5- Dietary behaviors, trying to lose weight or increase it, the foods that eaten in the past two days and the dietary habits of the student with (11) subscales.6- Physical inactivity, practicing regular physical activity, types of activities and participation in social services, with (3) subscales. 


\section{Scoring system:}

The items reported to be a YES answer were scored (1) and NO answer scored (0). These scores have converted into a percentage score. For each area of assessment data. These scores of the items and the total score divided by the number of these items.

\section{Scoring of the students unintentional injuries and violence}

The items reported to be usually answer was scored (1) and rarely answer scored (0), the item reported (don't drive) was scored (2), The items reported to be a yes answer were scored (1) and a no answer scored (0). The items of suicide causes was scored (1-6).

\section{Scoring of the students Smoking behavior}

The students reported smoke was scored (1), and not smoke scored (0), smoking, type, days, cigarettes count and smoking rate scored (1-3), smoking age scored (1-4).

\section{Scoring of the students alcohol and drug abuse}

The students reported drink alcohol was scored (1), and not drink scored (0), alcohol drinking age and days scored (1-4), alcohol drinking amount scored (1-3), the students reported drug abuse was scored (1), and not abuse scored (0), drug types scored (1-7), drug abuse age and days scored (1-4), finally, the students reported using sedatives without prescription scored (1), and those no scored (0).

\section{Scoring of the students Sexual behavior}

The students reported practice sex was scored (1), and the answers are no scored (0), sexual, age scored (1-4), sex partners scored (1-0), using the condom scored (1-0). Sexual enharrsment scored (1-2), AIDS test scored (1-0), testing reasons scored (1-3).

\section{Scoring of the students dietary behaviors}

The students reported tried to decrease or increase weight was scored (1), those reported no scored (0), The items reported to be a yes answer were scored (1) and no answer scored (0), The items reported to be usually answer was scored (1) and rarely answer scored (0). 


\section{Scoring of Physical inactivity}

The students reported practice regular exercise was scored (1), those answers no scored (0), sweeting activities, pulling, and walking activity days scored (1-3), social activity participation scored (1) and answers no scored (0).

\section{Content Validity}

Tools of data collection are tested for content validity by a panel of five experts in the field of Family and Community Health Nursing, Faculty of nursing (Port Said University). It is conducted to test the tool for appropriateness, comprehensiveness, relevance, and clearance. Their opinions are elicited regarding the tool format, layout, and consistency. The necessary modifications are done accordingly.

\section{Testing Reliability}

The reliability is assured by calculating Cronbach's Alpha Coefficients. Its value is (0.79), which indicates high reliability.

\section{Pilot study:}

The pilot study was carried out with $10 \%$ of study sample which included (70) students, ( $10 \%$ was selected from each faculty), which were equally selected of the first names in the classrooms. Checklist for first, second, third, and four years). it conducted over a period of with month from the beginning of October 2015 to the beginning of November 2015.the sample of the students included in the pilot study were excluded from the main study sample. The purposes of the pilot study were to test the applicability of the tool \& feasibility of the study. Find out the possible obstacles and problem that might face the researcher and interfere with data collection. Detect any problems peculiar to the statements as a sequence of questions and clarity. Estimate the time needed for data collection

\section{Administrative and Ethical Considerations:}

An official permission was obtained by submission of an official letter from the Faculty of Nursing to the deans of all the faculties of the study to obtain the authorization for data 
collection. The aim of the study was explained before participation, and voluntary participation was emphasized and an oral consent was obtained.

\section{Statistical Analysis}

Data were collected and entered into a database file. Statistical analyses were performed by using the Statistical Package for Social Science (SPSS), version 19. Data were described by summary tables and figures. Data were presented using proper statistical tests that were used to determine whether there were significant relations. Qualitative data were described and summarized using numbers and percentage. Comparison between different groups regarding categorical variables was tested using chi-square test and, fisher test. Reliability of statistics was assessed using Cronbach's ( $\alpha$ ) test.

\section{Field Work:}

Selected students were assured that the information given would be treated with confidentiality and used for the research purpose; they were also given an opportunity to refuse to participate. The purpose of the study was explained to each student agreed to participate in the study prior to answering the questionnaire sheet, then, an oral consent was obtained from them. The researcher knew and determined the suitable time to the students by the deans of each faculty according to their class schedule. Data were being collected from the selecting, setting by the researcher using the pre constructed tool at the time of the study. During the interviews, each item and question on the data collection tool explained the meaning by the researcher to the participants of students. The students were allowed to ask any interpretation or explanation. The study tool was filled by the students and it was distributed and answered within 20-30 minutes then collected. The questionnaires filled by the students while they were in break times or in the classroom.

The study was conducted from the beginning of February 2016 till the end of December 2016. Data was collected through about four days a month. The researcher were attending 16 days in three months, every week one day to collect about 40-50 questionnaire sheet. The present study consumed about 10 months, three month of them for obtaining the official permissions, pilot study and modifications of the tool. The next four months consumed for data collection while, the last three months of data entry and statistical analysis. 


\section{RESULTS:}

Table (1): shows that the age of the study participants (53.6\%) was 20years or more and $(46.4 \%)$ of them were less than 20years. As regards the gender, the students was enrolled $(67.6 \%)$ were females and (32.4\%) were male students. In relation to religions, the students participating in the study (95.4\%) were Muslims, and (5.6\%) were Christian. Regarding to the current house of residence, $(78.0 \%)$ the studied students are living in the family house, and $(22.0 \%)$ are living away from the family. In relation to the Current place of residence, (92.1\%) were inhibited in urban areas, and (7.9\%) were inhibited in rural area. Concerning the Crowding index, the studied students who live in crowded house are (62.4\%), not crowded (27.2\%), and only over crowded (10.4). With respect to Educational level of the father and the mother, the parents, education of the studied students (51.7\%) has higher education, (34.4\%) have middle education, while (12.2\%) are illiterate. The mothers' education of the studied students (46.2\%) has higher education, (39.3\%) has middle education, while $(12.8 \%)$ are illiterate. In addition to the monthly family income, $(80.4 \%)$ is enough, and (19.6) is not enough.

Figure (1): demonstrates that the unintentional injuries (16.7\%), and smoking behavior (11.0\%), drug abuse (5.9\%), sexual practice (6.3\%), unhealthy dietary behaviors (45.5) In addition to the students was not practicing physical exercise $(69 \%)$.

Figure (2): demonstrates that the students never or rarely use seat belt during transportation were $(89.1 \%)$, and $(79,5 \%)$ never use it during driving, the students always carrying a weapon $(6.3 \%)$ physical fights $(16.3 \%)$. In addition to the students that always was planning suicidal attempts $(10.9 \%)$.

Table (2): demonstrates that the family history of health risk behaviors in the study (36.9\%) was having Smoking, (24.7\%) were Overweight or obesity and (8.6\%) were Domestic violence, (3.1, and 2.6) respectively were Suicidal attempts, Drug abuse.

Table (3): shows that, there was a statistical significant relation between family suicidal attempts history and suicidal attempts, physical fights, smoking, and substance abuse behaviors of study students. There was a statistical significant relation between family domestic violence history and suicidal attempts and studied students physical fights. There was a statistical significant relation between family smoking history and smoking and studied students' substance abuse. There was a statistical significant relation between 
family alcohol consumption history and, physical fights, smoking, alcohol drinking and studied students substance abuse. There was a statistical significant relation between family substance abuse history and suicidal attempts, physical fights, smoking, drinking alcohol behaviors and studied students' substance abuse. There was a statistical significant relation between family obesity history and studied students' smoking.

Table (4): shows that there is a positive correlation between carrying weapon behavior and all other behaviors except sexual practice. There is a positive correlation between physical fights behavior and all other behaviors. There is a positive correlation between Suicidal attempts behavior and all other behaviors except alcohol use and sexual practice. . There is a positive correlation between Smoking behavior and all other behaviors. There is a positive correlation between Alcohol use behavior and all other behaviors except Suicidal attempts. There is a positive correlation between Drug abuse behavior and all other behaviors. There is a positive correlation between Sexual practice behavior and all other behaviors except carrying weapons and Suicidal attempts. 
Table (1): Distribution of the studied students according to their socio demographic data $(\mathrm{n}=700)$

\begin{tabular}{|c|c|c|}
\hline Items & $\mathbf{N}$ & $\%$ \\
\hline \multicolumn{3}{|l|}{ Age } \\
\hline Less than 20years & 325 & 46.4 \\
\hline 20years or more & 375 & 53.6 \\
\hline \multicolumn{3}{|l|}{ Gender } \\
\hline Male & 227 & 32.4 \\
\hline Female & 473 & 67.6 \\
\hline \multicolumn{3}{|l|}{ Religious } \\
\hline Muslim & 668 & 95.4 \\
\hline Christian & 32 & 4.6 \\
\hline \multicolumn{3}{|c|}{ Current house of residence } \\
\hline Family house & 546 & 78.0 \\
\hline Away from family & 154 & 22.0 \\
\hline \multicolumn{3}{|c|}{ Current place of residence } \\
\hline Urban & 645 & 92.1 \\
\hline Rural & 55 & 7.9 \\
\hline \multicolumn{3}{|l|}{ Crowding index } \\
\hline Over crowded & 73 & 10.4 \\
\hline Crowded & 437 & 62.4 \\
\hline Not crowded & 190 & 27.2 \\
\hline \multicolumn{3}{|c|}{ Educational level of the father } \\
\hline Illiterate, read and write & 87 & 12.4 \\
\hline Middle education & 245 & 35 \\
\hline Academic & 368 & 52.6 \\
\hline \multicolumn{3}{|c|}{ Educational level of the mother } \\
\hline Illiterate, read and write & 91 & 13 \\
\hline Middle education & 280 & 40 \\
\hline Academic & 329 & 47 \\
\hline \multicolumn{3}{|l|}{ Monthly family income } \\
\hline Enough & 563 & 80.4 \\
\hline Not enough & 137 & 19.6 \\
\hline
\end{tabular}




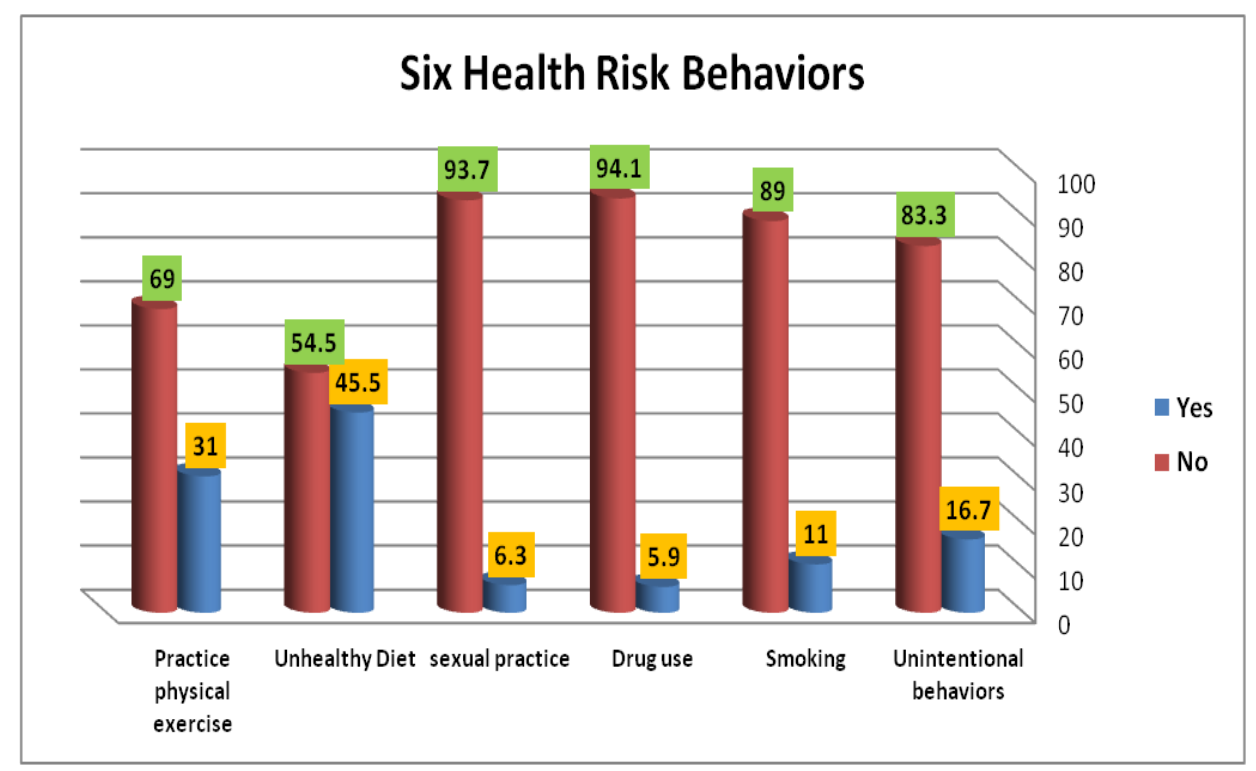

Figure (1): Distribution of the six health risk behaviors among Port Said University students

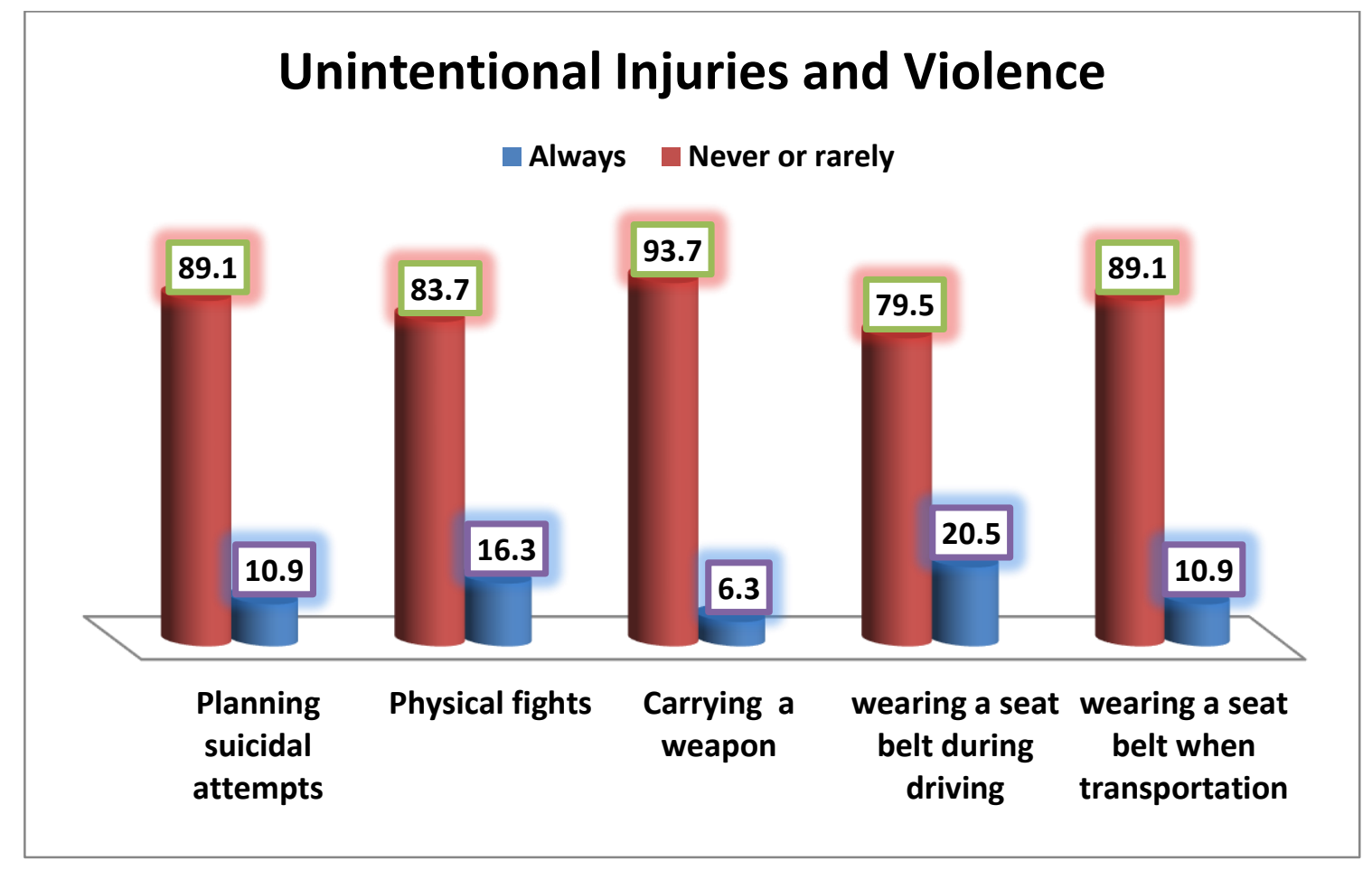

Figure (2): Distribution of the studied students, according to behaviors that leading to unintentional injuries and violence. $(n=700)$ 
Table (2): Distribution of the study group, according to family history of health risk behaviors. $(\mathrm{n}=700)$

\begin{tabular}{|l|c|c|}
\hline \multicolumn{1}{|c|}{ Family History } & N & $\%$ \\
\hline Suicidal attempts & 22 & 3.1 \\
\hline Domestic violence & 60 & 8.6 \\
\hline Smoking & 258 & 36.9 \\
\hline Alcohol use & 7 & 1.0 \\
\hline Drug abuse & 18 & 2.6 \\
\hline Overweight / obesity: & 173 & 24.7 \\
\hline
\end{tabular}


Table (3): Relation between family risk behaviors history and students risk behaviors.

\begin{tabular}{|c|c|c|c|c|c|c|}
\hline \multirow[b]{2}{*}{ Family } & \multicolumn{2}{|c|}{ Suicidal Attempts } & \multicolumn{2}{|c|}{ Physical fights } & \multicolumn{2}{|c|}{ Smoking } \\
\hline & yes & no & yes & no & yes & No \\
\hline \multirow[t]{2}{*}{\begin{tabular}{|l|} 
Suicidal attempts \\
\end{tabular}} & 14 & 8 & 9 & 13 & 8 & 14 \\
\hline & 62 & 616 & 105 & 573 & 69 & 609 \\
\hline Chil p-value & \multicolumn{2}{|c|}{$65.375^{a} / .000^{*}$} & \multicolumn{2}{|c|}{$10.101^{\mathrm{a}} / .005^{*}$} & \multicolumn{2}{|c|}{$14.926^{\mathrm{a}} / .001^{*}$} \\
\hline \multirow[t]{2}{*}{\begin{tabular}{|l} 
Domestic violence \\
\end{tabular}} & 15 & 45 & 21 & 39 & 10 & 50 \\
\hline & 61 & 579 & 93 & 547 & 67 & 573 \\
\hline Chil p-value & \multicolumn{2}{|c|}{$13.563^{\mathrm{a}} / .001^{*}$} & \multicolumn{2}{|c|}{$16.858^{\mathrm{a}} / .000^{*}$} & \multicolumn{2}{|c|}{$2.152^{\mathrm{a}} / .191$} \\
\hline \multirow[t]{2}{*}{ Smoking } & 31 & 227 & 48 & 210 & 39 & 219 \\
\hline & 45 & 397 & 66 & 376 & 38 & 404 \\
\hline \begin{tabular}{|l} 
Chil p-value \\
\end{tabular} & \multicolumn{2}{|c|}{$.566^{\mathrm{a}} / .453$} & \multicolumn{2}{|c|}{$1.612^{\mathrm{a}} / .205$} & \multicolumn{2}{|c|}{$7.072^{\mathrm{a}} / .012^{*}$} \\
\hline \multirow[t]{2}{*}{\begin{tabular}{|l|} 
Alcohol consumption \\
\end{tabular}} & 2 & 5 & 5 & 2 & 6 & 1 \\
\hline & 74 & 619 & 109 & 584 & 71 & 622 \\
\hline Chil p-value & \multicolumn{2}{|c|}{$2.292^{\mathrm{a}} / .171$} & \multicolumn{2}{|c|}{$15.770^{\mathrm{a}} / .002 *$} & \multicolumn{2}{|c|}{$40.317^{\mathrm{a}} / .000^{*}$} \\
\hline \multirow[t]{2}{*}{\begin{tabular}{|l|} 
Substance abuse \\
\end{tabular}} & 7 & 11 & 7 & 11 & 9 & 9 \\
\hline & 69 & 613 & 107 & 575 & 68 & 614 \\
\hline \begin{tabular}{|l|} 
Chil p-value \\
\end{tabular} & \multicolumn{2}{|c|}{$15.000^{\mathrm{a}} / .002 *$} & \multicolumn{2}{|c|}{$6.923^{\mathrm{a}} / .017^{*}$} & \multicolumn{2}{|c|}{$28.703^{\mathrm{a}} / .000^{*}$} \\
\hline \multirow[t]{2}{*}{\begin{tabular}{|l|} 
Overweight / obesity \\
\end{tabular}} & 23 & 150 & 30 & 143 & 27 & 146 \\
\hline & 53 & 474 & 84 & 443 & 50 & 477 \\
\hline \begin{tabular}{|l} 
Chil p-value \\
\end{tabular} & \multicolumn{2}{|c|}{$\frac{1}{1.411^{\mathrm{a}} / .260}$} & \multicolumn{2}{|c|}{$.188^{a} / .722$} & \multicolumn{2}{|c|}{$4.982^{\mathrm{a}} / .035^{*}$} \\
\hline
\end{tabular}


Comp Table (3): Relation between family risk behaviors history and students risk behaviors.

\begin{tabular}{|c|c|c|c|c|c|c|}
\hline Student & \multicolumn{2}{|c|}{ Alcohol use } & \multicolumn{2}{|c|}{$\begin{array}{c}\text { Substance } \\
\text { abuse }\end{array}$} & \multicolumn{2}{|c|}{ Obesity } \\
\hline & yes & no & yes & no & $\begin{array}{c}\text { overweigh } \\
t\end{array}$ & $\begin{array}{c}\text { Obes } \\
\text { e }\end{array}$ \\
\hline Suicide attempt & 2 & 20 & 5 & 17 & 4 & 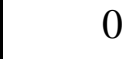 \\
\hline No & 18 & 660 & 16 & 662 & 129 & 30 \\
\hline Chil p-value & \multicolumn{2}{|c|}{$3.180^{\mathrm{a}} / .127$} & \multicolumn{2}{|c|}{$30.376^{\mathrm{a}} / .000^{*}$} & \multicolumn{2}{|c|}{$1.144^{\mathrm{a}} / .564$} \\
\hline Domestic violence & 3 & 57 & 2 & 58 & 11 & \\
\hline No & 17 & 623 & 19 & 621 & 122 & 28 \\
\hline Chil p-value & \multicolumn{2}{|c|}{$1.086^{\mathrm{a}} / .241$} & \multicolumn{2}{|c|}{$.025^{a} / .699$} & \multicolumn{2}{|c|}{$.273^{\mathrm{a}} / .872$} \\
\hline Smoking & 8 & 250 & 15 & 243 & 51 & 12 \\
\hline No & 12 & 430 & 6 & 436 & 82 & 1 \\
\hline Chil p-value & \multicolumn{2}{|c|}{$.087^{a} / .816$} & \multicolumn{2}{|c|}{11.118 a $/ .002 *$} & \multicolumn{2}{|c|}{$.197^{a} / .906$} \\
\hline Alcohol consumption & 3 & 4 & 5 & 2 & 2 & 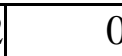 \\
\hline No & 17 & 676 & 16 & 677 & 131 & 30 \\
\hline Chil p-value & \multicolumn{2}{|c|}{$40.761^{\mathrm{a}} / .001 *$} & \multicolumn{2}{|c|}{$113.774^{\mathrm{a}} / .000^{*}$} & \multicolumn{2}{|c|}{.558 a $/ .756$} \\
\hline Substance abuse & 3 & 15 & 8 & 10 & 5 & i \\
\hline No & 17 & 665 & 13 & 669 & 128 & 29 \\
\hline Chil p-value & \multicolumn{2}{|c|}{$12.694^{\mathrm{a}} / .012 *$} & \multicolumn{2}{|c|}{$109.050^{\mathrm{a}} / .000 *$} & \multicolumn{2}{|c|}{$.661^{\mathrm{a}} / .719$} \\
\hline Overweight / obesity & 2 & 171 & 7 & 166 & 39 & \\
\hline No & 18 & 509 & 14 & 513 & 94 & 24 \\
\hline Chil p-value & \multicolumn{2}{|c|}{$2.396^{\mathrm{a}} / .186$} & \multicolumn{2}{|c|}{$.864^{a} / .439$} & \multicolumn{2}{|c|}{$2.085^{\mathrm{a}} / .353$} \\
\hline
\end{tabular}

*. Correlation is significant at the 0.05 level 
(Table 4): Correlation between studied student's health risk behaviors to each other.

\begin{tabular}{|c|c|c|c|c|c|c|c|c|}
\hline \multicolumn{2}{|c|}{ Correlations } & \multirow{2}{*}{$\begin{array}{r}\text { Carrying } \\
\text { weapon } \\
1\end{array}$} & \multirow{2}{*}{$\begin{array}{c}\text { Physical } \\
\text { fights } \\
\text {-.157-** }^{*}\end{array}$} & \multirow{2}{*}{$\begin{array}{c}\text { Suicidal } \\
\text { attempts } \\
-.118-^{* *}\end{array}$} & \multirow{2}{*}{$\begin{array}{l}\text { Smoking } \\
-.191 \text {-** }^{* *}\end{array}$} & \multirow{2}{*}{$\begin{array}{l}\text { Alcohol } \\
\text { use } \\
-.168-^{* *}\end{array}$} & \multirow{2}{*}{$\begin{array}{c}\text { Drug } \\
\text { abuse } \\
-.265-^{* *}\end{array}$} & \multirow{2}{*}{$\begin{array}{c}\begin{array}{c}\text { Sexual } \\
\text { practice }\end{array} \\
\text {-.054- }\end{array}$} \\
\hline Carrying & $\mathbf{P}$ & & & & & & & \\
\hline weapon & Sig. & ------- & .000 & .002 & .000 & .000 & .000 & .152 \\
\hline \multirow{2}{*}{$\begin{array}{l}\text { Physical } \\
\text { fights }\end{array}$} & $\mathbf{P}$ & $-.157-^{* * *}$ & 1 & $.244^{* *}$ & $.352^{* *}$ & $.157^{* *}$ & $.285^{* * *}$ & $.236^{* *}$ \\
\hline & Sig. & .000 & -------- & .000 & .000 & .000 & .000 & .000 \\
\hline \multirow{2}{*}{$\begin{array}{l}\text { Suicidal } \\
\text { attempts }\end{array}$} & $\mathbf{P}$ & $-.118-^{* *}$ & $.244^{* *}$ & 1 & $.112^{* * *}$ & .050 & $.100^{* * *}$ & $-.015-$ \\
\hline & Sig. & .002 & .000 & ------- & .003 & .183 & .008 & .698 \\
\hline \multirow[t]{2}{*}{ Smoking } & $\mathbf{P}$ & $-.191-^{* * *}$ & $.352^{* *}$ & $.112^{* *}$ & 1 & $.378^{* *}$ & $.473^{* *}$ & $.417^{* * *}$ \\
\hline & Sig. & .000 & .000 & .003 & --------- & .000 & .000 & .000 \\
\hline \multirow{2}{*}{$\begin{array}{l}\text { Alcohol } \\
\text { use }\end{array}$} & $\mathbf{P}$ & $-.168-^{* *}$ & $.157^{* *}$ & .050 & $.378^{* * *}$ & 1 & $.523^{* * *}$ & $.415^{* *}$ \\
\hline & Sig. & .000 & .000 & .183 & .000 & --------- & .000 & .000 \\
\hline \multirow{2}{*}{$\begin{array}{l}\text { Drug } \\
\text { abuse }\end{array}$} & $\mathbf{P}$ & $-.265-{ }^{* * *}$ & $.285^{* *}$ & $.100^{* *}$ & $.473^{* *}$ & $.523^{* * *}$ & 1 & $.299^{* *}$ \\
\hline & Sig. & .000 & .000 & .008 & .000 & .000 & -------- & .000 \\
\hline \multirow{2}{*}{$\begin{array}{l}\text { Sexual } \\
\text { practice }\end{array}$} & $\mathbf{P}$ & $-.054-$ & $.236^{* * *}$ & $-.015-$ & $.417^{* * *}$ & $.415^{* *}$ & $.299^{* * *}$ & 1 \\
\hline & Sig. & .152 & .000 & .698 & .000 & .000 & .000 & ------- \\
\hline
\end{tabular}

**. Correlation is significant at the 0.01 level 


\section{DISCUSSION:}

Risk health behaviors among university students are usually the major cause of morbidity and mortality during this period. University students are considered very important in our society and represent the future of families and communities and act as a role model for the public. However, they engage in risky behaviors that threaten both their current and future health. Understanding patterns and trends of risk behaviors among university students is of major importance for the assessment of the burden of these behaviors in the society and for determining the efforts to decrease it.

Health risk behaviors among the studied students in this study was found to be physical inactivity, followed by unhealthy dietary behavior, then unintentional injuries and violence. These findings are supported by (Amin, El-Shafie, Soliman, 2017) who revealed that the most risk taking behaviors among Nursing Students in Tanta university were unhealthy dietary behavior, violence and unintentional injuries, and physical in activity. Seat belt use has been demonstrated to save lives and reduce the severity of road traffic injuries. The current study indicated that the majority of the students in Port Said University never or rarely wear seat belt. This result is highly similar to the results of the study performed by (El-Gendy et al, 2015) who reported more half of the students in the University of Banha did not use a seat belt while driving. Moreover, also The Centers for Disease Control and prevention (CDC, 2008) reported that adults age 18-34 are less likely to wear seat belts than adults 35 or older.

Risk behaviors for youth violence, including carrying weapons can lead to serious injury or even death. The current study showed that the vast minority of students had reported that they were carrying weapons or guns (Kamal et al, 2010)who carried out their study about health risk behaviors among students of the private Egyptian university, where they found that only the least (2.9) of surveyed students carried a weapon during 6months before the survey; this could be attributed to that. Egyptian people did not like violence. 
Another behavior in youth violence is physical fights, Results of the current study also revealed that not a small proportion of students had participated in physical fights during the past 6 months preceding the survey your result is consistent with (Porter et al, 2009)who studied the priority of health behaviors in South African undergraduate students who enrolled in a large metropolitan university. He had reported that (12.0\%) of the students had been involved in at least one physical fight during the prior months. In contrast, Centers for Disease Control and prevention(CDC, 2013) reported that about the quarter of high school students reported being in a physical fight in the 12 months before the survey.

Another behavior that leading to intentional injury is attempting suicide, the present study showed that large percentage of the students had planning to attempt suicide during the past 6 months, The result is supported by (Kamal et al., 2010)who reported that $(8.7 \%)$ of the university students had seriously considered attempting suicide. Smoking behaviors remains a serious threat to global health, killing nearly 6 million people each year and causing excessive health care costs and lost productivity (WHO, 2015). It is another health risk behavior which is a critical health problem among university students in the world. However, the present study indicated that the few of the studied students were smokers. This is in the same line with the results of (Amin, El-Shafie, Soliman. 2017), who reported that the prevalence of smoking among the studied students in Nursing Students in Tanta university was $(6 \%)$.

Alcohol use is another risk behavior that has become a serious public health issue among university students in many countries. The current study revealed that, the majority of the students reported that they had never consumed alcohol; while only a small proportion of only of the studied students ever had alcohol drink. This is in accordance with(Amin, El-Shafie, Soliman. 2017), who reported that the few of the students were alcohol consumer among in Tanta university $(1.8 \%)$.

The present study indicated that the few of the studied students reported having risky sexual behavior.This is in line with (Abou Seif et al, 2011), who carried out a study to assess health risk behaviors among Ain-Shams University students and mentioned that 
prevalence of illegal sexual relations among the students was (5.8\%).Furthermore, the current study illustrated that only a small proportion of the studied students were sexually active, and more than one half of the sexually active students had their first sexual relation when they were between the ages of 16 to less than 20 years and the majority of those who sexually active did not use a condom during their last sexual relation.

The result is inconsistent with the study conducted by(Eaton et al, 2010)who found that $(34.2 \%)$ of the studied students were currently sexually active, (38.9\%) of currently sexually active students had not used a condom during their last sexual intercourse, The low prevalence in sexual risk behavior detected in the present study may be attributed to that as we are a part of Arab society and being an Islamic country this behavior is prohibited and not accepted at all in our society.

Concerning the statistical relationship between the students health risk behaviors and their family's history of health risk behaviors. Findings showed that there was highly statistically significant relation between the studied students' risk behaviors and their family's history of risk behaviors. These results supported by the results of

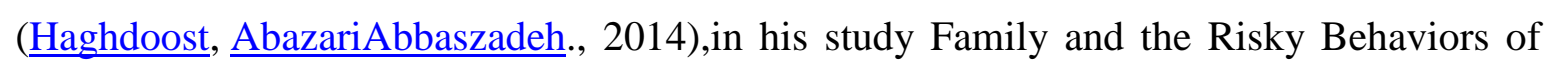
High School Students who mentioned that Adolescent in the families which excuse them for breaking the law are more likely to develop problems with risky behavior, Families whose parents engage in risky behavior inside or outside the home are at greater risks for exhibiting risky behavior, Adolescents whose parents practice drug abuse have higher tendencies towards risky behaviors because they watch their parents' behavior every day and attempt to select them as their models in life and act accordingly.

Concerning statistical correlation between students' health risk behaviors, findings showed that there was positively correlation between carrying a weapon, physical fights, suicidal attempts, smoking, drinking alcohol, substance abuse, and practicing sex behaviors. This result contrast with(Seedhom, 2017) in his study Health Risk Behaviors among School Adolescents; Types, Frequency and Predictors, Minia, Egypt, who said Correlation coefficients between tobacco use, alcohol consumption, substance use and sexual behavior were weak and fair relationship 


\section{CONCLUSION:}

Many of the studied students were engaged in many health risk behaviors that increasing their health at risk and live in danger. Male students were more likely than female students to engage in most of these health risk behaviors. Physical inactivity had been the most prevalent health risk behavior, followed by unhealthy dietary habits, then unintentional injuries and violence behaviors. Fortunately, the study found that the students were not invulnerable to alcohol or drug use, or sexual risk behavior. Male gender and not enough family income were a significant two factors in adopting unsafe behavior such as physical fight, drinking alcohol and drug abuse. . On the contrary the academic father education was a significant factor with student's healthy behaviors like the commitment of practicing physical activity, and prevent the suicidal attempts.

\section{RECOMMENDATIONS:}

\section{Recommendations for university students:}

Physical activities should be encouraged through applying well planned programs for the university students.

Nutritional programs are needed for university students to increase their awareness about healthy dietary behaviors.

Unintentional injuries and violence prevention education should be carried in the universities and public places as clubs, coffee shops and malls.

\section{Future Studies:}

Health education programs should be designed and directed to university students to prevent health risk behaviors through encouraging them to adopt healthy behaviors, to raise their awareness about the hazards of these risk behaviors and reinforce competence in adopting healthy behaviors.

\section{REFERENCES:}

Abou Seif H, Abou Elezz F, Elgaafary M, Ibrahem M and El Sotohy M., (2011): Health Risk Behaviors among University Students, Cairo, Egypt. The Egyptian Journal of Community Medicine,; 29 (3): 1-5. 
Amin A, El-Shafie I, Soliman F., (2017):Risk Taking Behaviors among Nursing Students IOSR Journal of Nursing and Health Science (IOSR-JNHS) e-ISSN: 23201959. P - ISSN: 2320-1940 Volume 6, Issue 5 Ver. II. (Sep. -Oct.2017), PP 7078www.iosrjournals.orgDOI: 10.9790/1959-0605027078 www.iosrjournals.org.Page.70

Ansari T, Alghamid T, Alzahrani M, Alfhaid F, Sami W, Aldahash B, et al. (2016): Risky health behaviors among students in Majmaah University, Kingdom of Saudi Arabia. J Family Community MED 23:133-139.

Bhuvaneswari K, Child and Adolescence Psychology. Bengaluru., (2014): CBS Publishers and distributors,; 208.

Center for Disease Control and Prevention CDC., (2008): Unintentional Injuries, Violence, and the Health of Young People. Division of Adolescent and School Health (DASH) National Center for Chronic Disease Prevention and Health Promotion (NCCDPHP). Atlanta, GA:USA November2008. Available from URL:Http: //Www.Cdc.Gov/Healthy youth/Injury/Pdf/Facts.Pdf.

Centers for Disease Control and Prevention (CDC) Data \& Statistics Fatal Injury Report for (2016). Suicide rates listed are Age-Adjusted Rates.

Centers for Disease Control and Prevention. Youth risk behavior surveillanceUnited States, (2013). Morbidity and Mortality Weekly Report (MMWR). Surveillance Summaries, 2016; 63(4): 1-172.

Eaton DK, Kann L, Kinchen S, Shanklin S, Ross J,Hawkins J, Harris WA, Lowry R, McManus T, Chyen D, Lim C, Whittle L, Brener ND, WechslerH; Centers for Disease Control and Prevention(2010): Youth risk behavior surveillance - UnitedStates, (CDC) MMWR Surveill Summ. 4;59(5):1-142.

El-Gendy S D, El-Gendy MF, Dawah AY, Eldesouky RS and Abd El-Raof M., (2015): Risky Road-use behavior among Students at the University of Banha, Egypt. Eastern Mediterranean Health Journal,; 21 (2): 120. 


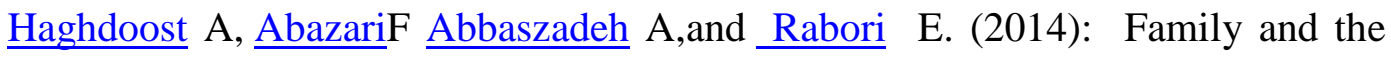

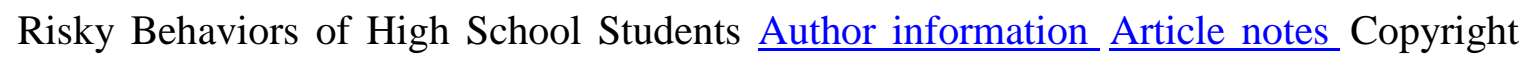
and License information.

Harbour C. Normative influences on youth in Minya, Egypt. (2010): Phylosophy doctor degree dissertation.; 11.

Abdel Aziz K., Nagy N., Shehad I., and Samir I. (2010): Health Risk Behaviors among Students of Private Universities in Egypt Current Psychiatry; Vol. 17, No. 1, 4953.

Lundy K, Janes S (2016): Community health nursing: caring for the public's health. 3rd ed. USA: Jones \& Bartlett Company. pp. 345-360.

McDermott E. Promoting Positive Development.,(2012): Family Process and Risk Behavior among Adolescents. PhD Sc. Thesis. College of Arts and Sciences. Florida International University.

Porter K, Johnson P and Petrillo J. (2009):Priority Health Behaviors among South African

Undergraduate Students. International Electronic Journal of Health Education; 12: $222-243$.

Seedhom AE. Health Risk Behaviors among School Adolescents;(2017): Types, Frequency and Predictors, Minia, Egypt. SM J Public Health Epidemiol.; 3(1): 1036.

UNAIDS/PCB and WHO. Thematic Segment: (2013): HIV, Adolescents and Youth Background. UNAIDS (United Nations Programme on HIV/AIDS) Programme Coordinating Board,; 13 (33): 3- 27.

WHO. (2011): Global HIV AIDS Response - Epidemic update and health sector progress towards Universal Access - Progress report 2011. 
World Health Organization. WHO., (2015): Report on the global tobacco epidemic,. Geneva, Switzerland: WHO; 2015.

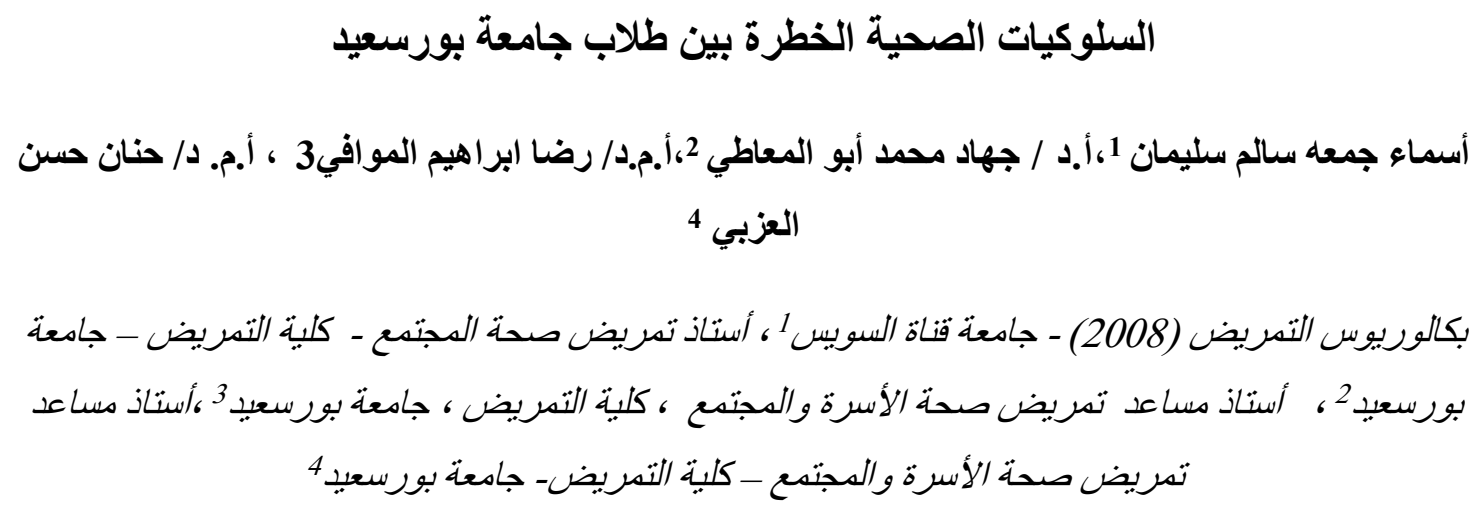

\section{الـخـلاصـــة}

تعتبر السلوكيات الصحية الخطرة واحدا من اهم جوانب الصحة للانسان خاصة فى مرحلة المراهقة والتعليم الجامعى.هدف الدراسة هو تقييم السلوكيات الصحية الخطرة بين طلاب جامعة .الدراسة وصفية، وأجريت الدراسة فى جميع الكليات ببورسعيد حيث شملت العينة 700طالب وطالبة وأختيرت بالطريقة الطبقية العشو ائية. تم جمع البيانات

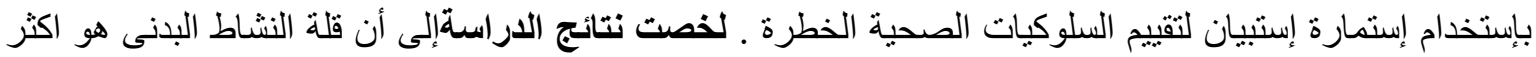
السلوكيات الخطرة انتشارا (69 \%) تتبعه التغذية الغير سليمة (45.5\%)ثم العنف و السلوكيات المتعلقة بالاصابات الغير متعمدة (16.7\%). أظهرت النتائج وجود علاقة ذات دلالة إحصائية بين العوامل البيئية والاجتماعية والعائلية وممارسة تلك السلوكيات الصحية الخطرة .استتتجت الدراسة ان لحسن الحظ ان السلوكيات مثل التدخين(11.0\%) وتعاطى الكحول(2.9\%) و المخدرات(3.0\%) وايضا السلوكيات الجنسية الخطرة (6.3\%) كانت قليلة بين طلاب جامعة بورسعيد،. وأوصت الدراسة بتنفيذ بر امج التتقيف الصحي في الجامعات و المخيمات الصيفية وفي الأماكن العامة لزيادة وعيهم بمخاطر هذه السلوكيات الخطرة وتعزيز الكفاءة في تبني السلوكيات الصحية. يجب إجراء المزيد من الأبحاث ، في الجامعات الأخرى في مصر ، لتحديد حجم المشكلة ضد طلاب الجامعات. 